\title{
MITOLOGI ANAK-ANAK ALLAH DI DALAM KEJADIAN 6:2
}

\author{
Oky Otto Otto*
}

Dosen di Sekolah Tinggi Teologi Biblika Jakarta

Diterima: 2 Maret 2020; Disetujui: 18 Maret 2020; Dipublikasikan: 6 April 2020

\begin{abstract}
Abstrak
Penafsiran Akitab terus berkembang dengan penemuan-penemuan metode hermeneutika dan bukti-bukti sejarah. Ayat-ayat yang sulit menjadi tantangan bagi setiap teolog untuk menemukan makna yang dimaksud oleh teks. Penafsiran mengenai siapa anak-anak Allah di dalam Kejadian 6:2 dan keturunannya menjadi diskusi yang menarik untuk terus diteliti. Penafsiran yang benar tentu akan menegaskan ajaran Kristen dan membantu penerapan kehidupan rohani bagi orang percaya. Pendekatan metode kualitatif dengan metode penafsiran historical-gramatical digunakan untuk meneliti siapa anak-anak Allah di dalam Kejadian 6:2 dan dampaknya terhadap keturunan kemanusiaan di bumi. Literatur-literatur kuno seputar dunia Timur Tengah kuno dapat memberikan sumbangsih mengenai pemahaman budaya pada saat itu sehingga dapat memberikan pengetahuan mengenai anak-anak Allah dalam tulisan Musa. Kesimpulannya adalah tidak pernah ada keturunan hybrid yang dihasilkan dari perkawinan manusia dengan malaikat yang jatuh.
\end{abstract}

Kata Kunci: Penafsiran, Anak-anak, Allah

\begin{abstract}
Bible interpretation always develops with hermenutics methods and historical proofs. For a theologian difficult text is a challenge to find the meaning reffered by the text. Interpretation about who is the childrens of God in Genesis 6:2 dan their descendants would be interesting to study. The right interpretation will confirm Christian doctrines and help the spiritual life application for the believers. A qualitative method approached with historical-gramatical interpretation method applied to studi who were sons of God in Genesis 6:2 and the impact in humanity descendants on earth. Ancient literatures around Near East world will give contribution to understand the cultures at that time and knowledges about sons of God in Moses's writing. The conclusion is that there was no hybrid descendants generated from marriaged between human with fallen angels.
\end{abstract}

Key Words: Interpretation, Sons, God

How to Cite: Dr. Oky Otto Otto, M.Th. (2020). Mitologi Anak-Anak Allah Di Dalam Kejadian 6:2. Jurnal Teologi Biblika, 5 (1): 24-35.

*Corresponding author:

ISSN 2355-1704 (Print)

E-mail:okyotto@yahoo.com 


\section{PENDAHULUAN}

Pernyataan "anak-anak Allah" di dalam Kejadian 6:2 telah menjadi kontroversi yang menarik di kalangan teolog. Penafsiran yang muncul mengenai siapa "anak-anak Allah" ini di bagi menjadi dua bagian besar, yaitu menunjuk kepada manusia atau para malaikat (yang jatuh). ${ }^{1}$ Kedua penafsiran tersebut memberikan dampak teologis yang cukup signifikan mengenai keberadaan mahluk hidup yang pernah ada di dalam dunia ini.

Sentral permasalahan adalah identifikasi dari "anak-anak Allah" di dalam teks tersebut. Tulisan ini berupaya untuk melihat klasifikasi dari dua pemikiran atau penafsiran besar di atas dan mencoba membahas dasar dari kedua pandangan besar mengenai siapa "anak-anak Allah" yang ada di dalam teks tersebut. Tiap-tiap penafsiran melihat kecenderungan dari salah satu prinsip dari hermeneutika.

1. mencoba melihat dari sisi gramatika dan konteks penggunaan kata "anak-anak Allah" di dalam Alkitab.

2. Berusaha membangun dari konteks kejatuhan dan alur keturunan di kitab Kejadian.

3. Melihat sisi historis dari literatur-literatur kuno mengenai anak-anak Allah.

4. Mempertimbangkan doktrin sistematika dengan melihat sifat dari malaikat itu sendiri yang tidak menikah dari perkataan Yesus.

Penelitian adalah untuk melihat keberatan-keberatan atau kesulitan-kesulitannya pada setiap tafsiran. Pada akhir akhir akan diambil konklusi dari penelitian yang telah dilakukan dan dampak teologisnya.

\section{METODE PENELITIAN}

Pendekatan penelitian ini merupakan penelitian kualitatif dengan menggunakan penafsiran historikal-gramatikal. Penafsiran Alkitab adalah penelitian teologi biblika yang mencakup teologi eksegesis dan kajian Alkitab. ${ }^{2}$ Prinsip penafsiran historikal-gramatikal adalah metode yang berusaha menemukan makna bagian Kitab Suci sesuai dengan tuntutan kaidah gramatika dan jenis sastra, fakta sejarah dan kerangka konteks. Ini merupakan pendekatan terbaik karena berkenaan dengan unsur-unsur inilah penafsir harus sepakat dengan penulis Alkitab supaya dapat menemukan makna yang dimaksudkannya.

Tehnik pengumpulan data yang digunakan oleh peneliti adalah: Pertama, dengan melakukan penafsiran terhadap teks Alkitab dengan metode historikalgramatikal. Kedua melakukan studi perbandingan penafsiran-penafsiran utama masa kini mengenai anak-anak Allah di Kejadian 6:2. Ketiga, membuat analisis kritis membangun rekonstruksi sejarah dan mempertimbangkan metode penulisan kuno.

\section{ASPEK-ASPEK PENTING DALAM TEKS Anak-Anak Allah}

Istilah "anak-anak Allah" di dalam teks Ibrani adalah $b^{e} n^{\hat{e}} h \bar{a}^{\check{e}} l o ̄ h i ̂ m$ yang artinya anak-anak Allah. Tidak ada penjelasan konteks dekat mengenai apa yang dimaksud dengan frasa ini. Konteks Perjanjian Lama merujuk pada referensi yang muncul di dalam Alkitab (Ayb. 1:6; 2:1; 38:7; Dan. 3:25; band. Mzm. 29:1; 89:7). ${ }^{4}$

\footnotetext{
${ }^{1}$ Crossway, ESV Study Bible (Wheaton: Crossway, 2008), 61.

${ }^{2}$ Andreas B. Subagyo, Pengantar Riset Kuantitatif dan Kualitatif (Bandung: Yayasan Kalam Hidup, 2004), 125.

${ }^{3}$ John D. Grassmick, Prinsip-prinsip dan Praktek Eksegesis Bahasa Yunani, diterjemahkan oleh Petrus Maryono, STTII, Yogyakarta, t.t.

${ }^{4}$ Thomas L. Constable, Notes on Genesis (http://www.soniclight.com/, 2012), 72.
} 
Namun frasa ini tidak eksklusif hanya untuk malaikat saja. Perlu kiranya dipertimbangkan bahwa sebutan "anak Allah" merupakan sebutan juga bagi Israel (Kel. 4:22; Ul. 4:23; 14:1; Yer. 31:20; Hos. 1:10; 11:1) dan bagi raja mereka (Mzm. 2:7; Mzm. 89:26-27; 2 Sam 7:14). ${ }^{5}$

Adanya tulisan-tulisan ekstrabiblikal yang mirip dengan peristiwa air bah dari budaya Mesopotamia, seperti lempengan Gilgamesh. ${ }^{6}$ Daftar raja-raja Sumeria dan Akadia memiliki juga kemiripan dengan umur-umur leluhur dari keturunan Set yang ditulis di dalam Kejadian 5. Catatan Ur-Isin dari Babel ( \pm tahun 1812 SM) contohnya menulis pemerintahan dari raja En-men-lu-Anna selama 43.200 tahun atau raja Enmen-gal-Anna yang memerintah selama 28.800 tahun. Dan setelah peristiwa air bah maka umur pemerintahan raja-raja ini tereduksi menjadi 140-1200 tahun saja. ${ }^{7} \mathrm{Di}$ dalam tulisan Ugarit anak-anak Allah adalah anggota-anggota dari pantheon atau rajaraja terkenal di bumi. ${ }^{8}$

\section{Perkawinan}

Perkawinan yang terjadi di dalam Kejadian 6:1-4 ini adalah suatu penyimpangan perkawinan yang telah didirikan Allah sebelumnya (Kej. 2). ${ }^{9}$ Perkawinan yang terjadi merupakan poligami, ${ }^{10}$ dan orgy yang banyak dipraktekkan oleh para penyembah-penyembah berhala dan ritual-ritual kafir. Pendapat lain juga mengatakan bahwa perkawinan ini merupakan tindakan penindasan "right of the first night" dari raja-raja di dalam kisah di Gilgamesh. Para raja-raja ini melakukan apa yang menjadi haknya sebagai wakil dari para allah masuk dalam malam pertama dengan perempuan siapa saja dalam pernikahan, lambang sebuah upacara kesuburan. ${ }^{11}$ Ini bukan perkawinan yang menyenangkan Tuhan tetapi dosa yang mencemarkan perintah perkawinan yang Tuhan berkati sebelumnya. Dosa yang terus menerus dilakukan oleh manusia semenjak kejatuhan.

\section{Nephilim}

Kata $n^{e}$ philim atau orang-orang raksasa di dalam Kejadian 6:4 ini juga perlu dipertimbangkan. Kata ini sebenarnya berarti "jatuh" atau memiliki hubungan dengan kejahatan. Istilah $n^{e}$ philim menekankan kejahatan dan tidak adanya rasa hormat satu dengan yang lain. ${ }^{12}$ Kata ini kembali muncul di dalam Bilangan 13:33 setelah persitiwa penghukuman Allah sehingga menjadi pertanyaan apakah keturunan ini adalah orang-orang raksasa yang ada di dalam Kejadian 6 ?

Rita Wahyu menjelaskan bahwa kaum $n^{e}$ philim ini adalah manusia biasa, bukan keturunan hybrid (campuran) antara malaikat dan manusia, dan bukan mahluk jadi-jadian yang diterjemahkan dengan gigantes oleh versi Septuaginta. Kata $n^{e}$ philim adalah bentuk jamak dari kata nafil yang akar katanya adalah nafal, artinya jatuh.

\footnotetext{
${ }^{5}$ G. T. Burke, "Son of God" dalam Evangelical Dictionary of Theology, peny. um., Walter A. Elwell (Grand Rapids: Baker Academic, 2001), 1125-6.

${ }^{6}$ Tremper Longman III, Panorama Kejadian: Awal Mula Sejarah, pen. Paul Hidayat (Jakarta: Scripture Union Indonesia, 2016), 96-97.

${ }^{7}$ Zondervan, NIV Archaelogical Study Bible (Grand Rapids: Zondervan, 2005), 12.

${ }^{8}$ John Walvoord dan Roy B.Zuck, peny., The Bible Knowledge Commentary (Wheaton: Victor Books, 1986), 36.

${ }^{9}$ Longman III, Panorama Kejadian, 143.

${ }^{10}$ John H. Walton, Victor H. Matthews \& Mark W. Chavalas, The IVP Bible Background Commentary: Old Testament (Downers Groves: IVP Academic, 2000), 36

${ }^{11}$ Ibid., 36

${ }^{12}$ Warren Baker, peny. um., The Complete Word Study Old Testament (Chattanooga: AMG Publishers, 1994), 17.
} 
Kata lainnya adalah kata nefel yang artinya gagal dan bukan besar atau raksasa. Kata raksasa atau besar biasanya di dalam bahasa Ibrani menggunakan kata anaqi atau anaq (Bil. 13:22; 28; 32; U1. 9:2; Yos. 15:13-14; 21:11; Hak. 1:20). ${ }^{13}$

\section{PEMIKIRAN MALAIKAT YANG JATUH}

Pandangan pertama yang menafsirkan bahwa "anak-anak Allah" di dalam Kejadian 6:2 menekankan akan arti kata di dalam teks tersebut. Pandangan tua yang berasal dari tradisi kuno Yahudi menafsirkan bahwa kemungkinan "mereka yang jatuh," adalah malaikat. Para malaikat ini telah diusir dari surga yang kemudian kawin dengan perempuan-perempuan manusia dan menghasilkan orang-orang yang gagah perkasa. Pandangan ini pada umumnya memiliki presuposisi bahwa ayat 1-4 adalah penjelasan singkat mitologi yang membantu memahami karakter-karakter kejahatan sebelum air bah. ${ }^{14}$

Walaupun dari kalangan rabi Yahudi menolak pandangan ini dan menyatakan bahwa "anak-anak Allah" merujuk pada hakim-hakim manusiawi. ${ }^{15}$ Namun penegasan dari sisi Yahudi lainnya datang dari tulisan Apokripa, yaitu Kitab Henokh. Di dalam 1Henokh pasal 6-36 berisi mengenai keberadaan malaikat dan alam semesta. Di dalam pasal 6-11 menulis mengenai kejatuhan malaikat yang adalah anak-anak Allah karena menikahi anak-anak manusia. Para malaikat ini kemudian mengajarkan berbagai macam ilmu dan kemampuan kepada manusia sehingga menjadi jahat. ${ }^{16}$

Salah satu dari cerita-cerita mitos mengenai demigods ini adalah dari kaum Hurian sekitar 1500 SM yang mengisahkan mengenai dewa-dewa yang memiliki relasi terlarang dengan manusia. Apakah pandangan kafir ini yang menjadi landasan dari Kejadian 6:1-4? Atau cerita yang dari bangsa-bangsa berhala ini kemudian dimodifikasi sehingga menghasilkan teks di dalam Kejadian untuk kerusakan yang terjadi di atas muka bumi. ${ }^{17}$

Thomas L. Constable mengatakan bahwa pandangan yang mengatakan "anakanak Allah" adalah malaikat merujuk pada referensi yang muncul di dalam Alkitab (Ayb. 1:6; 2:1; 38:7; Dan. 3:25; band. Mzm. 29:1; 89:7). ${ }^{18}$ Kyle M. Yates bersama

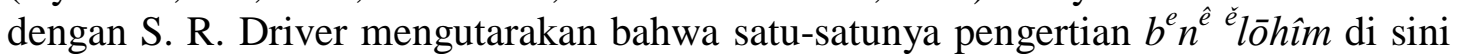
adalah anggota mahluk-mahluk surgawi milik Allah. Penerjemahan secara harafiah akan menghasilkan pernyataan bahwa anggota masyarakat surgawi memilih perempuan-perempuan terpilih dari bumi untuk dinikahi dengan sesungguhnya. Para malaikat ini memiliki kekuatan yang besar untuk memaksa para perempuan bumi untuk mengikuti kehendak mereka. "Anak-anak Allah" ini tidak dapat dilawan menurut teks-teks Perjanjian Baru (2 Pet. 2:4; Yud. 1:6). ${ }^{19}$ Believer's Bible Commentary mendukung pendapat ungkapan Semitik "anak-anak Allah" sebagai

\footnotetext{
${ }^{13}$ Rita Wahyu, Eksegesis Peshat Kitab Kejadian (Malang: ISCS Lecture \& Discipleship, 2018), 421-22.

${ }^{14}$ H. van Broekhoven, "Nephilim," The International Standard Bible Encyclopedia, peny., um., Geoffrey W. Bromiley 4 Jil. (Michigan: Eerdmans Publishing, 1979), 3:519.

${ }^{15}$ Allen P. Ross, Creation \& Blessing: A Guide To The Study and Exposition of Genesis (Grand Rapids: Baker Book House, 1988), 178.

${ }^{16}$ H. G. Andersen, , "Enoch, Book Of," The Zondervan Pictorial Encyclopedia of the Bible, peny. um., Merrill C. Tenney, 5 jil. (Grand Rapids: Zondervan, 1976), 2:309.

${ }^{17}$ G. H. Livingston, "Sons of God" The Zondervan Pictorial Encyclopedia of the Bible, peny. um., Merrill C. Tenney, 5 jil. (Grand Rapids: Zondervan, 1976), 5:493.

${ }^{18}$ Thomas L. Constable, Notes on Genesis (http://www.soniclight.com/, 2012), 72.

${ }^{19}$ Kyle M. Yates, "Kejadian," The Wycliffe Bible Commentary, peny. Charles F. Pfeiffer dan Everett F. Harrison, pen. Penerbit, 3 Jil. (Malang: Gandum Mas, 2004), 1:50-51.
} 
istilah malaikat-malaikat. Penjelasan Yudas 1:6-7 menegaskan bahwa para malaikat keluar dari batas-batas yang ditentukan dan berdosa seperti dosa yang dilakukan oleh Sodom dan Gomorah dalam hal perilaku seksual. ${ }^{20}$

Menurut pandangan ini maka keturunan-keturunan campuran malaikat dan manusia adalah semacam demigods atau manusia setengah dewa pada masa itu. Metode penafsiran yang terlihat di dalam pandangan malaikat yang jatuh ini sepertinya menekankan gramatika arti kata $b^{e} n^{\hat{e}} e^{\check{C}}$ lohîm dan penggunaan umum yang muncul di dalam Perjanjian Lama. Kesetiaan terhadap tehnik literal dan ketidaksalahaan Alkitab dan perbandingan konteks di dalam Alkitab menjadi dasar dari pandangan ini. Sepertinya sulit untuk tidak mempertimbangkan penggunaan $b^{e} n^{\hat{e}}$ ${ }^{\grave{e}}$ lōhim berdasarkan arti katanya secara literal sebagai suatu yang bersifat supranatural.

Pandangan kedua membatasi keturunan yang terjadi dari anak-anak Allah ini. Peter Gentry memberikan penafsiran yang sama bahwa anak-anak Allah di dalam Kejadian 6 ini adalah malaikat yang jatuh tetapi mengurung konteksnya sehingga peristiwa perkawinan ini tidak berdampak kepada keturunan manusia yang akan dibinasakan oleh Allah. Melihat waktu dari ungkapan di ayat 4 "Pada waktu itu" dan "pada waktu sesudah." Jika "Pada waktu itu" menunjuk pada waktu atau masa di ayat 1-3 sebelum air bah dan "pada waktu sesudah" menunjuk pada waktu atau masa sesudah air bah maka seharusnya keturunan demigods ini atau $n^{e}$ philim terus berlanjut (Bil. 13:22; 28; 33). Menurut beliau frasa "dan juga pada waktu sesudah" ('ahareken) muncul di kalimat kedua. Kata "'ahare-ken" dimodifikasi oleh kalimat relatif yang secara khusus untuk peristiwa di ayat 2 sehingga kata "Pada waktu itu" menunjuk pada kaum $n^{e}$ philim yang sudah ada sebelum terjadinya perkawinan antara malaikat dengan manusia.

Interpretasi di atas didukung oleh gramatika teks. Ayat 4 terdiri dari 2 klausa atau kalimat, pertama verba dan kedua nomina. Keduanya ditandai dengan asyndeton (tidak ada penghubung di awal klausa/kalimat). Kalimat pertama kata kerjanya noninisial. Pola ini adalah memasukkan suatu penjelasan akan sesuatu yang menyimpang. Faktanya kalimat pertama adalah subjek-inisial menunjukkan suatu topik baru. Kalimat relatif di ayat 4 menghubungkan topik baru ini dengan peristiwa di ayat 2 . Kalimat nomina ini kemudian menjelaskan tentang $n^{e}$ philim. Mereka adalah orangorang perkasa dari zaman dahulu. Inilah yang dimaksud oleh penulis dengan "Pada waktu itu" atau masa sebelum peristiwa di ayat 2 sehingga penulis sepertinya mendemitologisasikan $n^{e}$ philim. Orang-orang perkasa ini telah ada sebelum dan sesudah perisitiwa di ayat 2 dan tidak memiliki kaitan dengan orang-orang perkasa ( $n^{e}$ philim) ini. Jadi ayat 1 menjelaskan bertambahnya jumlah anak-anak perempuan manusia, ayat 2 menjelaskan hubungan malaikat-malaikat dengan manusia, ayat 3 menyimpulkan bahwa hasilnya tetap manusia sehingga menjadi sebab penghukuman Allah dan ayat 4 menyatakan bahwa semua ini tidak ada kaitannya dengan $n^{e}$ philim karena kata $n^{e}$ philim tidak dijelaskan lebih lanjut, mereka hanya orang-orang perkasa yang yang sudah diketahui oleh pembaca.

Penyimpangan yang terjadi ini menunjukkan bahwa jika seseorang berasumsi bahwa Kejadian 6:1-4 adalah perkawinan antara malaikat dan manusia maka ini tidak ada hubungannya dengan penyebab dari hukuman air bah. Dengan demikian penghukuman malaikat di dalam 2 Petrus 2:4 dan Yudas 1:6 tidak terkait dengan hukuman air bah. ${ }^{21}$

\footnotetext{
${ }^{20}$ William MacDonald, Believer's Bible Commentary (Nashville: Thomas Nelson Publishers, 1995), 39.

${ }^{21}$ Peter J. Gentry dan Stephen J. Wellum, Kingdom Through Covenant (Wheaton: Crossway, 2012), 149-51.
} 
Pandangan Gentry sepertinya mempertimbangkan faktor sifat dari malaikat yang tidak kawin (Mat. 22:30) dalam pengertian tidak menghasilkan suatu keturunan demigods. Tafsiran ini masih tetap mendukung bahwa anak-anak Allah adalah malaikat yang jatuh tetapi melepaskannya dari keseluruhan konteks penghukuman air bah yang ditumpahkan Allah akibat dosa-dosa manusia.

\section{PEMIKIRAN MANUSIA YANG JATUH}

Pandangan kedua mengenai $b^{e} n^{\hat{e} ~}{ }^{c}$ lōhîm adalah melihat keberadaannya sebagai manusia. Menurut pemikiran ini kembali ada beberapa tafsiran mengenai keberadaan manusia yang dimaksud. Dua pandangan pertama melihat secara literal dari anakanak Allah ini yang diidentifikasikan dengan manusia dan dua pandangan kemudian melihat dari sisi tulisan-tulisan kuno yang mempengaruhi penulisan Kejadian mengenai orang-orang yang dianggap super, namun adalah manusia.

Pandangan pertama melihat bahwa "anak-anak Allah" ini adalah keturunan Set yang menyembah Tuhan. Di dalam Keluaran 4:22, Israel disebut sebagai anak Allah tetapi sebutan ini bukanlah penggunaan umum di dalam Perjanjian Lama. Israel sebagai anak merupakan pilihan Allah. Sebutan "anak" juga menunjukkan sebuah subordinasi anak kepada bapa dan kasih bapa yang dicurahkan bagi anaknya, dalam hal ini Israel sebagai anak sulung Allah. ${ }^{22}$ John H. Sailhamer mengatakan bahwa "anak-anak Allah" ini melanjutkan konteks sebelumnya mengenai keturunan Set. Menurut beliau ayat 1-4 memberikan introduksi penyebab dari terjadinya air bah. ${ }^{23}$ Keturunan Set ini sebagai "anak-anak Allah" mengawini keturunan Kain yang jahat. Hal ini mengikuti konteks yang berjalan dari pasal 4 dan pasal 5. Konteks juga menekankan adanya dua keturunan dari jalur yang berbeda yang menjadi gambaran sebuah persekutuan yang ditentang oleh Allah sehingga mengakibatkan hukuman air bah. ${ }^{24}$ Tafsiran ini sepertinya lebih menekankan konteks dari kisah Kejadian yang dimulai dari jalur Set dan bercampur dengan perkawinan dari jalur Kain.

Rita Wahyu menjelaskan lebih lanjut bahwa "anak-anak Allah" adalah dari generasi Set yang saleh sedangkan generasi Kain yang jahat bergelar "anak-anak manusia." 25 Beliau menulis bahwa jika "anak-anak Allah" adalah malaikat yang jatuh adalah setan atau iblis sedangkan anak-anak Allah adalah malaikat yang suci (Ayb. 1:6; Mzm. 29:1; 89:7; Dan 3:25) maka tidak mungkin gelar ini dikenakan pada setan/iblis (malaikat yang jatuh). Perkawinan ini tidak memiliki dasar karena malaikat sendiri tidak menikah (Mt. 22:30), perkawinan yang terjadi adalah perkawinan campur antara keturunan manusia yang saleh (Set) dan yang jahat (Kain) sehingga garis keturunan ini akan membahayakan rencana keselamatan Allah melalui Mesias. Ia mengutip ayat-ayat berkenaan dengan gelar anak-anak Allah bagi keturunan Set (Luk. 3:36; 38). Dari keturunan Set ini (anak-anak Allah) menurunkan Nuh. Set sebagai pengganti Habel mengungkapkan harapan yang saleh, yaitu dengan kelahiran Nuh yang nantinya akan melahirkan Mesias, Sang Penebus yang akan mengakhiri kutuk dosa yang mengancam Adam dan keturunannya (Kej. 5:29; bandingkan Kej. $3: 15 ; 17$ dst). Efek perkawinan campur yang negatif ini menjadi dasar bagi Paulus

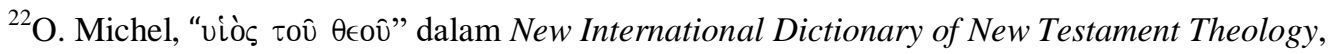
peny. um., Colin Brown, 4 vol. (Grand Rapids: Zondervan, 1986), 3:636.

${ }^{23}$ John H. Sailhamer, "Genesis" dalam Zondervan NIV Bible Commentary, peny. um., Kenneth L. Barker dan John R. Kohlenberger III, 2 vol. (Grand Rapids: Zondervan, 1994), 1:15.

${ }^{24}$ MacDonald, Believer's Bible Commentary, 39.

${ }^{25}$ Wahyu, Eksegesis Peshat, 405.
} 
kemudian menulis 2 Korintus 6:14 berdasarkan pasangan yang tidak seimbang di Perjanjian Lama (Im. 19:19; Ul. 22:10). ${ }^{26}$

Rabbi Menachem Davis mengutip beberapa pendapat rabbi di dalam bukunya Commentary on Chumash bahwa "anak-anak Allah" (gender maskulin) adalah anakanak Set sedangkan "anak-anak manusia" (gender feminin) adalah anak-anak Kain, seorang yang terkutuk dan hidup dalam kegelapan, sebagaimana anaknya Lamekh (Kej. 4:17-19; 23-24). ${ }^{27}$

Pandangan yang kedua mengatakan bahwa "anak-anak Allah" adalah orangorang kenamaan atau raja-raja yang berkuasa pada saat bertambahnya jumlah manusia di bumi (Kej. 6:1). Keberadaan dari para penguasa ini tidak terlepas dari para malaikat yang jatuh. Kemungkinan para malaikat yang jatuh ini menguasai hidup atau merasuki para penguasa dunia ini.

Thomas L. Constable memberikan beberapa argumentasi terhadap tafsiran ini. Menurut beliau literatur-literatur Timur Tengah kuno seringkali menulis mengenai raja-raja yang berkuasa sebagai "anak Allah" atau titisan dewa. Kejadian 6:1-4 ini memiliki kemiripan dengan tulisan-tulisan Babel kuno mengenai kisah sebelum air Bah. Demikian juga tulisan Perjanjian Lama mengenai hakim-hakim di dalam Mazmur menulis pada mereka adalah elohim atau ilahi. ${ }^{28}$

Perlu kiranya dipertimbangkan bahwa sebutan "anak Allah" bukan hanya merupakan sebutan bagi Israel saja (Kel. 4:22; Ul. 4:23; 14:1; Yer. 31:20; Hos. 1:10; 11:1) tetapi juga bagi raja mereka (Mzm. 2:7; Mzm. 89:26-27; 2 Sam 7:14) ${ }^{29}$ Secara khusus menunjuk kepada Anak Allah sejati, Mesias Israel, yaitu Yesus. Pandangan yang sama mengatakan bahwa penyebutan "anak-anak Allah" seringkali digunakan untuk para raja (Kel. 21:6; 22:8; Mzm. 82:6-7). ${ }^{30}$

Pandangan ketiga, yang hampir serupa dengan yang di atas, adalah kombinasi dari pandangan pertama (malaikat-malaikat yang jatuh) dan sedikit modifikasi dari pandangan kedua (manusia/ raja-raja tetapi yang berkuasa saat itu). Malaikat-malaikat yang jatuh ini meninggalkan habitatnya dan menguasai para raja-raja dan orang-orang kenamaan di bumi. Kita tahu dari Daniel 10:13; 20 bahwa raja-raja terkenal dan kerajaan-kerajaan dunia memiliki "pemimpin/pangeran" kegelapan di belakang mereka. Roh-roh yang berkuasa ini bertempur dengan Michael (penghulu malaikat). Demikian juga di dalam (Yeh. 28:11-19), raja Tirus diasosiasikan dengan setan, salah satu kerub pilihan. Tidak heran jika literatur-literatur kuno Timur Tengah menganggap raja-raja sebagai ilahi, setengah ilahi atau demigods (seperti pandangan kedua di atas). Para penyembah berhala menganggap para pemimpin ini sebagai dewa atau setengah dewa. Dalam budaya Ugarit istilah "anak-anak Allah" adalah anggota dari pantheon (kumpulan semua dewa-dewa) sebagaimana raja-raja yang berkuasa di bumi. Salah satu cerita dari legenda Ugarit adalah kepala pantheon, El, sudah menjadi tua dan dalam sebuah upacara ia menggoda 2 perempuan manusia. ${ }^{31}$ Contoh Firaun sebagai "anak Allah" dapat menjadi gambaran bagi orang-orang Israel akan keadaan manusia zaman dahulu yang berkuasa.

Jadi raja-raja dan orang kenamaan (yang jahat) pada masa itu jelas dilatarbelakangi oleh kuasa setan yakni para malaikat yang jatuh dan mengawini para perempuan-perempuan. Hal ini sesuai dengan konteks dan budaya mitologi pada saat

\footnotetext{
${ }^{26}$ Wahyu, Eksegesis Peshat, 410-12.

${ }^{27}$ Wahyu, Eksegesis Peshat, 407.

${ }^{28}$ Thomas L. Constable, Notes on Genesis (http://www.soniclight.com/, 2012), 72.

${ }^{29}$ Burke, Son of God, 1125-6.

${ }^{30}$ Baker, Word Study Old Testament, 17.

${ }^{31}$ Ross, Creation \& Blessing, 181-82.
} 
itu. Penafsiran ini menjelaskan mengenai kejahatan umat manusia dan bukan sebuah mahluk campuran yang mempunyai benih yang berbeda dari benih Adam.

Tafsiran ini melihat tidak hanya dari segi arti kata $b^{e} n^{\hat{e}} h \bar{a}^{e} l o \bar{h} \hat{\imath}$ tetapi juga mempertimbangkan konteks dan ditambah dengan sisi historis dari kebiasaan budaya setempat, khususnya gaya penulisan literatur kuno. Tujuan utama dari teks harus menjadi penekanan disini yaitu kejahatan manusia pada ayat 5 .

Penulis memasukkan pandangan keempat dengan mempertimbangkan pengalaman dan konteks pembaca pertama, yaitu bangsa Israel yang telah 4 abad diperbudak di Mesir dan sedang menuju tanah Kanaan yang dikuasai oleh bangsabangsa yang berperawakan besar-besar. Bangsa Israel bukanlah bangsa yang canggih dalam hal militer, tidak seperti bangsa-bangsa Kanaan.

Sepertinya ada kaitan antara $n^{e}$ philim (jamak maskulin) yang sudah ada dengan "anak-anak Allah" (jamak maskulin) yang kemudian menikahi anak-anak perempuan manusia (jamak feminin) dari keturunan Set yang dijelaskan keturunannya di pasal 5. Kemungkinan besar $n^{e}$ philim adalah anak-anak dari keturunan Kain yang memang jatuh tetapi memiliki kekuasaan yang besar di bumi dan kemudian disebut dengan anak-anak Allah ini. Keturunan campuran ini kemudian memperanakkan orang-orang gagah perkasa (hagiborim) dan kenamaan pada zaman itu tetapi jahat di mata Tuhan. Bangsa Israel sedang dalam perjalanan menuju tanah Kanaan yang dihuni oleh orang-orang yang dianggap raksasa dan penuh dengan raja-raja perkasa. Mereka memandang diri sebagai budak yang keluar dari Mesir dan tidak memiliki kekuatan menghadapi orang-orang yang tinggal di Kanaan (Bil. 13:28-33). Namun dalam pandangan Allah mereka ini adalah orang-orang yang jahat sehingga Israel diperintahkan untuk memerangi dan membinasakan orang-orang di tanah Kanaan (Kel. 23:23; 33:2; 34:11; Ul. 7:1; 20:17; Yos. 3:10 dll). Analogi-analogi mengenai siapa Kanaan ini (Kej. 9:18-27) menjadi referensi bagi bangsa Israel untuk maju menduduki tanah yang dijanjikan Allah. Pada akhirnya Allah akan menghukum dan membinasakan orang-orang jahat walaupun mereka adalah orang-orang perkasa dan kenamaan, lebih dari Israel yang baru keluar dari perbudakan di Mesir tanpa pengetahuan mengenai senjata dan pengalaman berperang. Allah yang memberikan perintah kepada bangsa Israel adalah Allah Pencipta Langit dan Bumi yang telah memilih suatu umat pilihan bagi diriNya.

Pandangan ini mencoba melihat tulisan-tulisan mitologi kuno yang memang memperlihatkan raja-raja Sumeria yang berumur panjang seperti juga keturunanketurunan yang dicatat oleh Alkitab di Kejadian 5 sehingga sedikit banyak mendemitologisasikan manusia yang gagah perkasa saat itu. Dan melihat konteks keturunan ilahi dari Set dan keturunan Kain yang jahat yang akan menerima penghukuman Allah melalui air bah serta sifat malaikat yang memang tidak menikah.

\section{PEMIKIRAN MITOS}

Di dalam The Jewish Study Bible tidak terlalu menekankan pentingnya hal ini dengan mengatakan bahwa narasi tersebut merupakan kondensasi dari mitos atau legenda terkenal yang lebih panjang. ${ }^{32}$ Hal ini tidak mengherankan bagi pandanganpandangan liberal. Oleh sebab itu perlu adanya kajian yang kemudian memiliki kebenaran teologis yang benar sehingga Alkitab secara keseluruhan merupakan suatu

\footnotetext{
${ }^{32}$ Adele Berlin dan Marc Zvi Brettler, peny., The Jewish Study Bible (New York: Oxford University Press, 2004), 21.
} 
yang dipandang sesuai dengan fakta historis dan bukan berisi mitos atau legenda kuno serta harmonis adanya.

Pandangan nomor 3 dan 4 dari pemikiran manusia yang jatuh melihat genre sastra dari Kejadian 1-11 yang dipengaruhi oleh mitologi kuno saat itu. Memang benar bahwa ayat-ayat Perjanjian Lama memiliki kesamaan dengan konsep-konsep mitologi Timur Dekat kuno. Hal ini tidak usah terlalu ditakuti oleh orang Kristen masa kini. Tidak ada risiko adaya kesalahan pada pesan-pesan teologis ataupun keberadaan Allah sendiri. Allah memberikan wahyu kepada para penulis dengan budaya dan pengetahuan yang berlaku saat itu untuk dapat dikomunikasikan dengan pembaca dan orang-orang pada masa itu. ${ }^{33}$ Para ahli saat ini harus dapat mengambil pesan dengan melihat kembali dan mengkodefikasi konsep-konsep mitologi yang masuk ke dalam Alkitab. Secara tehnis istilah "mitos" seringkali dianggap suatu yang tidak real atau rekaan, namun sebenarnya mitos adalah berkaitan dengan realitas walaupun mengendap di dalam cerita, kisah puitis tetapi bukan fantasi. Peter Eens mengatakan bahwa mitos adalah sebuah genre sastra yang tidak harus terlihat seperti sebuah catatan sejarah tetapi dapat ditulis dalam bentuk puisi dan menggunakan bahasa-bahasa simbol. Contohnya adalah cerita air bah yang tidak saja tertulis di Alkitab tetapi juga di dalam tradisi Mesopotamia. ${ }^{34}$

Vern S. Poythress menjelaskan bahwa istilah mitos adalah sebuah kata "licin," yang seringkali menunjukkan suatu yang dikarang atau tidak benar. Ia menulis,

It is better, then, not to use such a slippery word. Or if we do, use it consistently. (Below I will use it in its popular sense, a made-up story that includes superhuman characters.) Perhaps we want to consider stories that involve the actions of superhuman beings, either gods or superhuman heroes. These sto- ries occurred in the ancient world, and typically they were fanciful and polytheistic. But the central question remains, "How do we know whether the gods or superhuman heroes actually existed?" Those who listened to the sto- ries may possibly have had a number of attitudes. Greek philosophers questioned the validity of some of the ancient stories about the Greek gods. Perhaps, centuries earlier, some skeptically minded people questioned the Mesopotamian and Canaanite and Egyptian stories too. We do not know for sure. But typically the people of the Near East accepted the real existence of the gods, as is proved by their willingness in times of desperation even to offer a child in sacrifice to a god (Lev. 18:21; 2 Kings 16:3; Ps. 106:38). In calling the stories about ancient gods "myths," we modern people agree that these gods were illusory. The stories were counterfeits. But they were counterfeits of something true. False gods counterfeit the true God, and replace worship of the true God with a substitute, corrupt worship. But they are close enough to the truth to entice people into the falsehood. ${ }^{35}$

Menurut beliau kisah di dalam Kitab Kejadian adalah kisah yang benar-benar terjadi dengan menggunakan bahasa yang fenomenal, bahasa yang biasa digunakan pada masa Israel kuno.

Kevin Vanhoozer di dalam bukunya Remythologizing Theology menjelaskan perbedaan pemahaman myth dan mitos. Myth adalah kisah suci atau kisah dari pada allah (dewa-dewi) yang secara khusus terjadi dalam waktu dan ruang yang suci di luar

\footnotetext{
${ }^{33}$ Walton, The IVP Bible Background, 31.

${ }^{34}$ Zondervan, In The Beginning: Three Views on The Bible's First Chapter, e-book, Zondervan Academic, 2015.

${ }^{35}$ Vern S. Poythress, Redeeming Science: A God Centered Approach (Wheaton: Crossway Books, 2006), 91.
} 
dari fakta sejarah dan biasanya menyangkut perkataan dan tindakan supra-manusia. Plato menggunakan tehnik myth ini untuk mengkomunikasikan sebuah kebenaran universal. Mitos adalah dramatisasi peristiwa utama dari sebuah cerita. Perbedaan mitos dengan myth adalah pertama, mitos berkaitan dengan peristiwa di dunia ini daripada dunia lain. Kedua, arti dan kebenaran tentang mitos berkaitan dengan cara bagaimana sebuah tindakan dilakukan. Jadi mitos Alkitab adalah untuk mengindikasikan seluruh peristiwa yang kompleks tidak hanya menunjukkan sebuah tindakan tetapi juga realitas mengenai Allah. ${ }^{36}$

Orang Kristen perlu terlalu anti dengan penulisan-penulisan Alkitab yang menyerupai tulisan-tulisan mitos budaya yang beredar saat itu. Ini bukan berarti mengindikasikan bahwa tulisan Alkitab tidak terjadi secara fakta sejarah tetapi mempertimbangkan metode penulisan sastra kuno dimana Alkitab merupakan bagiannya dan juga pola pemahaman orang Israel yang keluar dari tanah Mesir pada abad 12 sebelum masehi.

\section{SIMPULAN}

Penjelasan mengenai "anak-anak Allah" di Kejadian 6:2 telah menjadi perdebatan yang cukup panjang. Apakah memang malaikat atau manusia? Kesulitannya adalah karena perkataan Yesus mengenai malaikat (Mat. 22:30). Walaupun malaikat ini telah jatuh dan memiliki kekuatan supranatural tetapi apakah tetap dapat melakukan perkawinan di luar batas-batas yang ditentukan? Mengapa tidak hal tersebut terjadi lagi sekarang ini? Walaupun ada banyak cerita bahwa manusia dapat kawin mengawin dengan bangsa jin. Namun jika melihat konteks, alasan penghukuman air bah, dosa dan sifat penciptaan malaikat maka kecenderungan mengarah bahwa "anak-anak Allah" di dalam Kejadian 6 ini adalah manusia.

Tidak ada keberadaan malaikat di dalam pasal-pasal sebelumnya, dapat menjadi indikasi bahwa sebenarnya Musa tidak sedang berbicara mengenai malaikat tetapi manusia-manusia yang memang berasal dari ilahi atau paling tidak dianggap ilahi oleh masyarakat kuno termasuk Israel pada saat itu dan kemudian jatuh atau menjadi jahat karena dosa. Satu-satunya keberadaaan mahluk ilahi adalah kerub penjaga taman Eden. Tidak ada yang menjadi pendahuluan dari keberadaan malaikat. Tidak ada konteks dekat yang dapat dijadikan patokan mengenai siapa "anak-anak Allah," khususnya di dalam Kitab Pentateuk. Konteks terdekat mungkin di Kitab Ayub atau Mazmur. Hal ini membuat sulit untuk menyatakan bahwa "anak-anak Allah" ini adalah malaikat dari sisi penulisan Pentateuk. Tujuan teks adalah menjelaskan pertambahan jumlah manusia yang terus menerus berbuat kejahatan dan layak untuk dihukum dengan air bah.

Semua pandangan-pandangan ini memiliki argumentasinya yang kuat karena berpegang pada salah satu aspek prinsip-prinsip hermeneutika (gramatika, konteks, historis dan teologis). Namun konteks memiliki penekanan yang paling kuat. Gramatika dari Peter Gentry perlu dipertimbangkan bahwa keturunan yang dimaksud adalah tetap anak-anak manusia dan bukan campuran malaikat yang jatuh dengan manusia (hybrid) walaupun terjadi perkawinan antara malaikat dan manusia. Penjelasan Rita Wahyu juga perlu diperhatikan mengenai gramatika dari kata $n^{e}$ philim yang menekankan kaum yang jatuh sesuai dengan konteks bahwa penghukuman air bah adalah karena Allah melihat kejahatan manusia.

2010), 3-7

${ }^{36}$ Kevin Vanhoozer, Remtythologizing Theology (New York: Cambridge University Press, 
Kesimpulan akhir adalah melihat konteks penghukuman air bah disebabkan oleh kejahatan manusia. Jika anak-anak Allah ini memang adalah malaikat yang jatuh dan menikahi perempuan-perempuan manusia namun keturunan dari perempuanperempuan manusia ini tetaplah manusia dan bukan hasil dari perkawinan berbeda sifat ciptaan. Frasa "perempuan-perempuan itu melahirkan anak bagi mereka" sedikit banyak menjelaskan mengenai keturunan ular yang terus bermusuhan dengan keturunan ilahi yang kemudian menurunkan Mesias (Kej. 3:15). Walaupun keturunan ini adalah tetap benih manusia, kesulitannya adalah bagaimana itu bisa terjadi?

Konteks lebih mendukung bahwa anak-anak Allah ini adalah ras manusia yang perkasa dan kenamaan namun jahat dari keturunan Kain dan kawin dengan perempuan-perempuan manusia keturunan Set. Bagian ini merupakan referensi dan keyakinan bagi bangsa Israel untuk bersiap memasuki tanah perjanjian yang diperuntukkan oleh Allah pencipta langit dan bumi yang akan menyertai mereka menduduki dan memerangi bangsa Kanaan.

\section{DAFTAR PUSTAKA}

Andersen, H. G., "Enoch, Book Of." The Zondervan Pictorial Encyclopedia of the Bible. Disunting oleh Merrill C. Tenney. 5 jilid. Grand Rapids: Zondervan, 1976.

Baker, Warren. The Complete Word Study Old Testament. Chattanooga: AMG Publishers.

Berlin, Adele dan Marc Zvi Brettler. The Jewish Study Bible. New York: Oxford University Press, 2004.

Broekhoven, H. van. "Nephilim." The International Standard Bible Encyclopedia. Disunting oleh Geoffrey W. Bromiley. 4 Jilid. Michigan: Eerdmans Publishing, 1979.

Burke, G. T. "Son of God." Evangelical Dictionary of Theology. Disunting oleh Walter A. Elwell. Grand Rapids: Baker Academic, 2001.

Constable, Thomas L. Notes on Genesis (http://www.soniclight.com/, 2012.

Gentry, Peter J. dan Stephen J. Wellum, Kingdom Through Covenant (Wheaton: Crossway, 2012.

Grassmick, John D. Prinsip-prinsip dan Praktek Eksegesis Bahasa Yunani. diterjemahkan oleh Petrus Maryono. STTII, Yogyakarta, t.t.

Livingston, G. H. "Sons of God." The Zondervan Pictorial Encyclopedia of the Bible. Disunting oleh Merrill C. Tenney. 5 jilid. Grand Rapids: Zondervan, 1976.

Longman III, Tremper. Panorama Kejadian: Awal Mula Sejarah. Diterjemahkan oleh Paul Hidayat. Jakarta: Scripture Union Indonesia, 2016.

MacDonald, William. Believer's Bible Commentary. Nashville: Thomas Nelson Publishers, 1995.

Michel, O. "vì̀s tôิ $\theta \in \mathrm{ou} . "$ New International Dictionary of New Testament Theology. Disunting oleh Colin Brown. 4 Volume. Grand Rapids: Zondervan, 1986.

Poythress, Vern S. Redeeming Science: A God Centered Approach. Wheaton: Crossway Books, 2006.

Ross, Allen P. Creation \& Blessing: A Guide To The Study and Exposition of Genesis. Grand Rapids: Baker Book House, 1988.

Sailhamer, John H. "Genesis." Zondervan NIV Bible Commentary. Disunting oleh

Kenneth L. Barker dan John R. Kohlenberger III. 2 Volume. Grand Rapids: Zondervan, 1994.

Subagyo, Andreas B. Pengantar Riset Kuantitatif dan Kualitatif. Bandung: Yayasan 
Kalam Hidup, 2004.

Vanhoozer, Kevin Remtythologizing Theology. New York: Cambridge University Press, 2010.

Wahyu, Rita. Eksegesis Peshat Kitab Kejadian. Malang: ISCS Lecture \& Discipleship, 2018.

Walton, John H., Victor H. Matthews \& Mark W. Chavalas. The IVP Bible Background Commentary: Old Testament. Downers Groves: IVP Academic, 2000.

Walvoord, John dan Roy B. Zuck. The Bible Knowledge Commentary. Disunting oleh John Walvoord dan Roy B. Zuck. Wheaton: Victor Books, 1986.

Yates, Kyle M. "Kejadian." The Wycliffe Bible Commentary. Disunting oleh Charles F. Pfeiffer dan Everett F. Harrison. Diterjemahkan oleh Penerbit. 3 Jilid. Malang: Gandum Mas, 2004.

Zondervan. In The Beginning: Three Views on The Bible's First Chapter, e-book, Zondervan Academic, 2015.

Zondervan, NIV Archaelogical Study Bible. Grand Rapids: Zondervan, 2005. 